\title{
Honey Bee Tracheal Mite, Acarapis woodi (Rennie) (Arachnida: Acarina: Tarsonemidae) ${ }^{1}$
}

\author{
H. A. Denmark, H. L. Cromroy and Malcolm T. Sanford ${ }^{2}$
}

\section{Introduction}

In October 1984, the honey bee tracheal mite, Acarapis woodi (Rennie), was found in Florida. Although it was first described by Rennie in 1921, the mite was not found in the United States until 1984. Rennie described the mite from bees on the Isle of Wight and associated it with the "Isle of Wight" disease. Symptoms of this infestation were described as "bees crawling about unable to fly, and with wings disjointed; dwindling and mortality of colonies have been said to occur rapidly with colonies dying within a month." It was later shown that the tracheal mite was not the cause of the "Isle of Wight" disease (Bailey 1964), and later reports (Bailey 1968, Morse 1978) indicate that $A$. woodi is not as serious a pest of honey bees as previously thought. In combination with other adverse conditions, however, heavy mite infestations may cause a reduction in bee activity.

\section{Distribution}

With the exception of Australia, New Zealand, Scandinavia, and Canada, A. woodi has been found wherever honey bees are found (Delfinado 1963). In the United States, it was first found in Weslaco, Texas in July 1984, in New Iberia, Louisiana in August 1984, and in Florida, North Dakota, South Dakota, New York and Nebraska in October 1984.

\section{Description}

Female: Length 140 to 175 microns, width 75 to 84 microns. Idiosoma ovoid or nearly pyriform; dorsal shield and plates faintly sclerotized, with indistinct punctures. Propodosoma lacking pseudostigmatic sensilla; two pairs of long, attenuate setae, verticals V1 and scapulars Sce. V1 setae shorter than Sce, about 1/4 longer than distance between bases of setae Sce. Ventral apodemes I forming Y-shaped structure with anterior median apodeme (a conspicious transverse band crossing the thorax in front of the scutellum), not joining transverse apodeme. Apodemes III weakly extending laterad to bases of trochanters III. Apodemes IV extending to bases of trochanters IV. Posterior median apodeme rudimentary, sometimes as faintly formed Y-shaped structure. Leg 1 robust with single

1. This document is EENY-172 (originally published as DPI Entomology Circular 267), one of the Featured Creatures series of the Entomology and Nematology Department, Cooperative Extension Service, Institute of Food and Agricultural Sciences, University of Florida. Published: November 2000. This document is also available on Featured Creatures Website at http://creatures.ifas.ufl.edu. Please visit the EDIS Website at http://edis.ifas.ufl.edu. Additional information on these organisms, including many color photographs, is available at the Entomology and Nematology Department website at http://entnemdept.ifas.ufl.edu/.

2. H. A. Denmark, Florida Department of Agriculture and Consumer Services, Division of Plant Industry; H. L. Cromroy and Malcolm T. Sanford, Entomology and Nematology Department, University of Florida, Gainesville, FL.

The Institute of Food and Agricultural Sciences (IFAS) is an Equal Employment Opportunity - Affirmative Action Employer authorized to provide research, educational information and other services only to individuals and institutions that function without regard to race, creed, color, religion, age, disability, sex, sexual orientation, marital status, national origin, political opinions or affiliations. For information on obtaining other extension publications, contact your county Cooperative Extension Service office. Florida Cooperative Extension Service / Institute of Food and Agricultural Sciences / University of Florida / Larry R. Arrington, Interim Dean 
hooked claw. Legs II and III each with paired claws.

Leg IV stubby, widely spaced; femur-genu and tibiotarsus functioning as one segment; tibiotarsus IV two times as long as broad; femur-genu broader than long, with three setae unequal length; tibiotarsus abruptly narrowed, almost straight, about two times as long as broad. For a more complete description see Delfinado-Baker and Baker (1984).

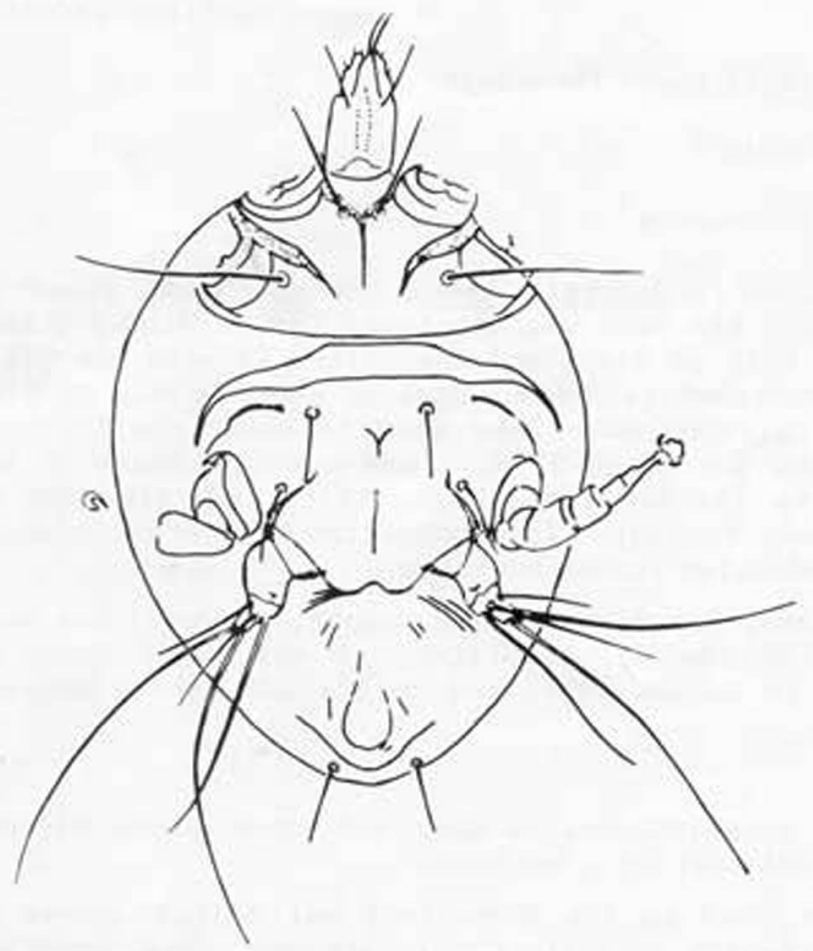

Figure 1. Adult female honey bee tracheal mite, Acarapis woodi (Rennie). Credits: Division of Plant Industry

Male: Length 125 to 136 microns, width 60 to 77 microns. Similar to female except for sexual differences. Apodemes III to IV not developed, barely discernible. Posterior median apodeme indistinct, sometimes forming weak Y-shaped structure. Apodemes $\mathrm{V}$ present as weakened transverse apodeme barely discernible. Leg I more robust than others. Leg IV short, about 3/4 as long as leg III, without claw; trochanter large, slightly longer than wide, with seta; femur-genu slightly more than two times as long as wide, without flanges, three setae of unequal length; tibiotarsus nearly straight, slightly shorter than femur-genu; apical with slender pointed solenidion and 1 very long seta. Males and nymphs are difficult to separate from other known species.

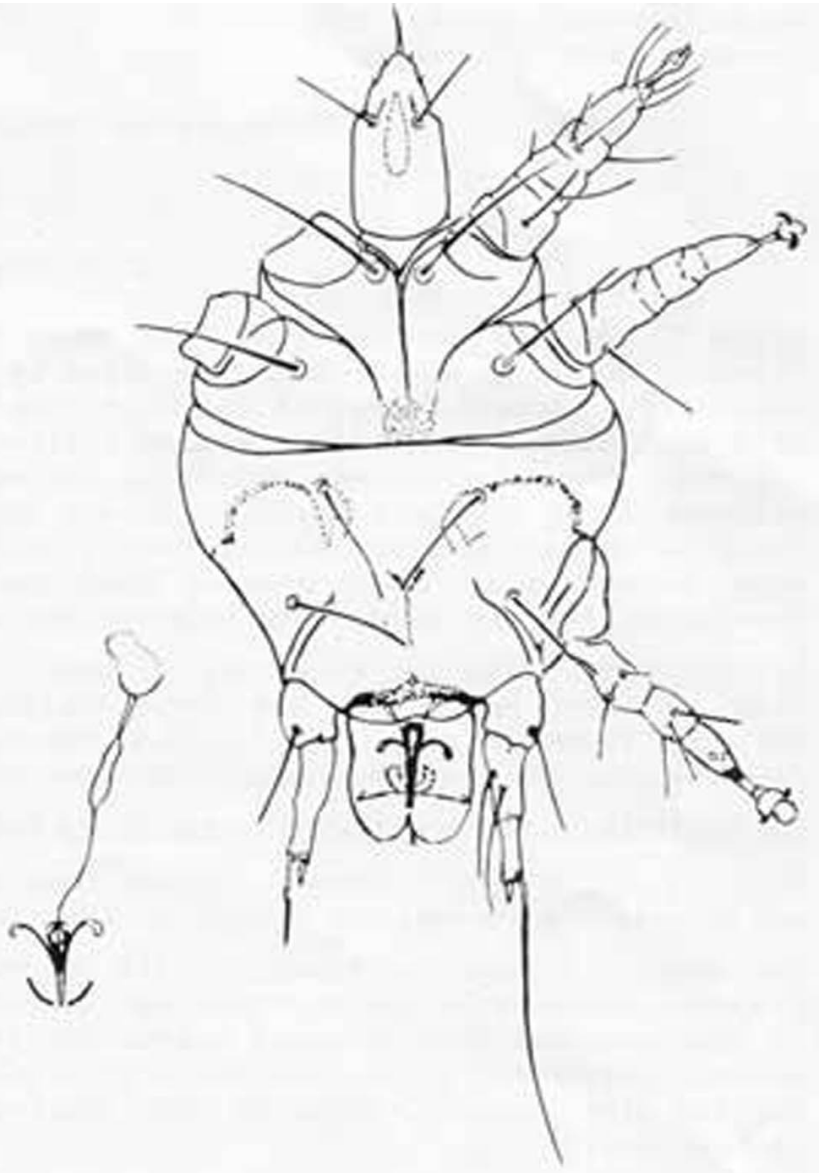

Figure 2. Adult male honey bee tracheal mite, Acarapis woodi (Rennie). Credits: Division of Plant Industry

\section{Life Cycle}

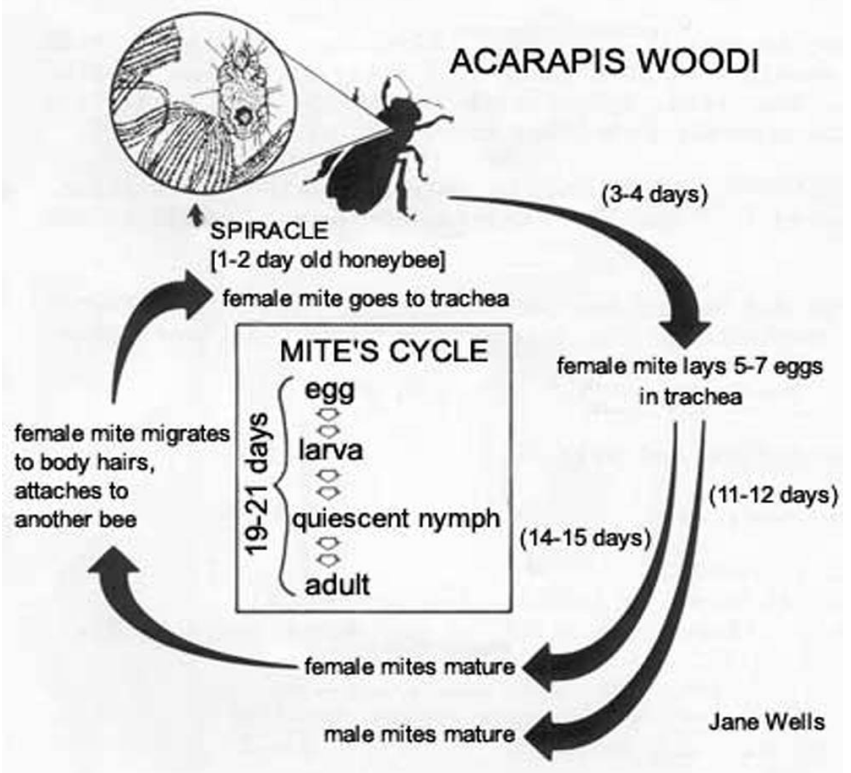

Figure 3. Life cycle of the tracheal mite of the honey bee. Credits: Division of Plant Industry 


\section{Host}

It is probably specific to the honey bees.

\section{Economic Importance}

Although it has been shown that a mite infestation does not cause acute disease and devastating losses, the life of bees may be shortened, but only by a few days.

The mites puncture the tracheal wall of young bees and feed in the haemolymph but do not appear to transmit diseases during this process. Infested bees may behave normally until they die or as described in the introduction. Infested queens can live for many years (Fyg 1964). Morse (1978) estimated a five percent reduction in the population of a colony of infested bees. Honey production and pollen collecting are also reduced. Colonies that develop severe infestations usually do so in late summer and die in late winter.

Some British bees and some North American strains show a certain amount of resistance to the mites (Bailey 1965). American bees are somewhat less resistant than the British bees.

\section{Survey and Detection}

A close examination of the trachea is required to determine mite infestation. Occasionally adult mites are found on the external surface of the bee. Gravid female mite crawls to the tip of a hair and attaches to a young bee. Generally, heavy infestations will show up as a darkened trachea; healthy tracheae without mites are clear to white under the microscope.

\section{Management}

Acaricides that have been tested in Europe and Mexico are Acarol, Menthol, and Folbex Forte. Currently, no decision has been made to use these controls in the United States. For further information see Guzman-Novoa and Zozaya-Rubio (1984). Formic acid has recently been approved under the name Apicure

Apicure : Formic Acid Treatment Becomes a Reality (http://apis.ifas.ufl.edu/apis_2000/apfeb_ 2000.htm\#5).

\section{Selected References}

Bailey, L. 1964. The Isle of Wight Disease: the origin and significance of the myth. Bee World 45: 32-37, 18.

Bailey, L. 1965. The effect of Acarapis woodi on honey bees from North America. Journal of Apicultural Research 4: 105-108.

Bailey, L. 1968. Honey bee pathology. Annual Review of Entomology 13: 191-212.

Definado, M.D. 1963. Mites of the honey bee in Southeast Asia. Journal of Apicultural Research 2: 113-114.

Definado-Baker, M., and E.W. Baker. 1984. Notes on honey bee mites of the genus Acarapis Hirst (Acari: Tarsonemidae). International Journal of Acarology 8: 211-266.

Fyg, W.W. 1964. Anomalies and diseases of the queen honey bee. Annual Review of Entomology 9: 207-224.

Guzman-Novoa, E., and A. Zozaya-Rubio. 1984. The effects of chemotherapy on the level of infestation and production of the honey in colonies of honey bees with acariosis. American Bee Journal 124: 669-672.

Morse, R.A. 1978. Arachnids: Acarina (mites and ticks), p. 197-209, In Morse, R.A., ed. Honey bee pests, predators, and diseases. Cornell University Press, Ithaca. 430 pp.

Rennie, J. 1921. Isle of Wight disease in hive bees - Acarine disease: The organism associated with the disease Tarsonemus woodi, n. sp. Transactions of the Royal Society of Edinburgh 52: 768-779. 